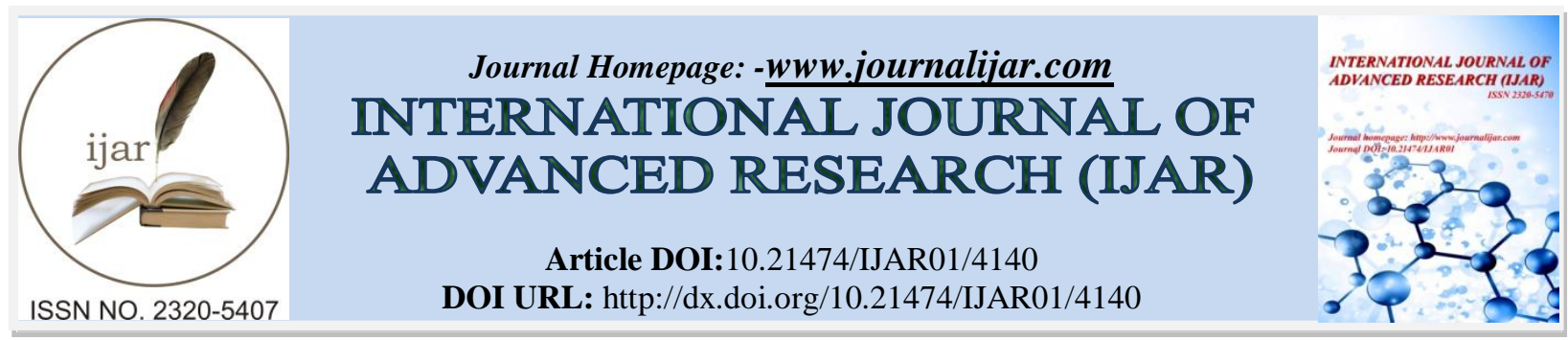

RESEARCH ARTICLE

\title{
CORRELATION BETWEEN TOXIC STRESS BY HEAVY METAL TOXICANTS AND PERIPHYTIC PROTOZOAN COLONIZATION RATES.
}

Neena Kumar ${ }^{1}$, Rashmi Saini ${ }^{1}$, Khushboo Chaudhary ${ }^{2}$, Muskaan Bansal $^{2}$, Kanika $^{2}$, and Namrata Pandey ${ }^{2}$.

1. Assistant Professor, Department of Zoology, Gargi College, University of Delhi, Delhi- 110 049, India.

2. Department of Zoology, Gargi College, University of Delhi, Delhi- 110 049, India.

\section{Manuscript Info}

Manuscript History

Received: 12 March 2017

Final Accepted: 16 April 2017

Published: May 2017

Key words:-

Metal toxicity, water pollution, pond ecosystem, Industrial wastes, Protozoan population, ecological markers.

\section{Abstract}

Metal pollution is considered hazardous to biological systems because of their toxic and carcinogenic potential. The behavioral, morphological and physiological changes have been prominently used in toxicity assessment studies in unicellular organisms. Recent studies have demonstrated that ciliates and flagellates play an important trophic role in periphytic communities and as bioindicator organisms for pollution degree in aquatic ecosystems. The present research was carried out to assess the correlation of toxic stress and deleterious impact of heavy metals (Copper, Cadmium, Zinc and Lead) on population densities of fresh water protozoans. Toxicity of four metals $\mathrm{Cu}^{2+}\left(\mathrm{CuSO}_{4} .5 \mathrm{H}_{2} \mathrm{O}\right), \mathrm{Cd}^{2+}\left(\mathrm{CdCl}_{2}\right), \mathrm{Zn}^{2+}\left(\mathrm{ZnSO}_{4}\right)$ and $\mathrm{Pb}^{2+}\left(\mathrm{Pb}\left(\mathrm{NO}_{3}\right)_{2}\right)$ were studied at three different concentrations $50 \mu \mathrm{g} / \mathrm{L}, 100 \mu \mathrm{g} / \mathrm{L}$ and $150 \mu \mathrm{g} / \mathrm{L}$ each. Direct count method was employed for enumerating the population densities and toxic stress responses were seen quantitatively as well as qualitatively. Colonization rates expressed by the species number over time obtained depicted a geometric regression of the average number of protozoans with increasing concentration of metals as compared with controls. Irregular beating of flagella and cilia and erratic and spinning movements of ciliates along with blebbing, stress egestions were observed in presence of these toxic metals. Copper was found to be least toxic followed by Cadmium, Zinc and Lead in terms of increasing toxicity. $\mathrm{Pb}$ and $\mathrm{Cd}$ form organometallic complexes, the toxicological properties of which can be more toxic than individual ions due to their high bioaccumulation tendencies. With significant metal uptake tendencies, protozoans can have a potential use in bioremediation of polluted waters.

Copy Right, IJAR, 2016,. All rights reserved.

\section{Introduction:-}

The term "heavy metals" is used by ecotoxicologists and environmental scientists for those metals which have highly toxic properties and deleterious impacts on organisms. Amongst all the heavy metals Mercury (Hg), Cadmium $(\mathrm{Cd})$, Copper $(\mathrm{Cu})$ and Lead $(\mathrm{Pb})$ are considered of prime concern because of their very high toxicological properties and irreversible effects on environment and living beings owing to their high accumulation tendencies (Patricia et.al., 2013 and Gupta et al, 2010) . 
Inputs of metals to environment takes place as a result of anthropogenic activities such as from erosion of rocks, wind blowing dusts, volcanic activity and forest fires etc. Release of toxic metals to aquatic environment also occurs because of mining operations, combustion of fuels by industrial, urban and agricultural practices (Depledge et. al., 1998 and Rang et. al., 1985). The characteristics and intensity of damage depends upon the nature and concentration of the metal.

The main purpose of biomonitoring of heavy metal concentrations is to determine toxicological threat posed to living beings including health risks to humans. Protozoans are an important component of food webs in the aquatic ecosystems and exhibit significant characteristics in defining structure and functioning of ecosystems and play pivotal role as nutrient releaser from bacterial biomass on phytoplanktons of pond water. The advantage of using protozoans is because they are unicellular organisms in close contact to the surrounding environment and show high sensitivity to wide range of xenobiotics and intoxicants found in diverse ambient aquatic habitats due to their simple construction, small individual sizes, large relative surfaces and weak self-protection. Because of very short generation time and high reproductive potential, short life cycles, it is feasible to evaluate the effects of toxicants on the growth, reproduction, metabolism and other biochemical processes of several generations of protozoans in short time, which takes several days, months, and even years for superior animal assays (Tsui et al., 2004). $\mathrm{Cd}$ and $\mathrm{Pb}$ form organometallic complexes, the toxicological properties of which can be more toxic than individual ions because of their high bioaccumulation tendencies. Microorganisms have ability to grow in presence of heavy metals. With significant metal uptake tendencies, protozoans can have potential use in bioremediation of polluted waters (Valvanidis, A. and Vlachogianni, T., 2010) and ciliates have been especially utilized as bioindicator organisms for bioaccumulation of metals in food chain (Gupta and Shukla, 1996). The present study was thus undertaken to decipher the impact of toxic stress by heavy metals on population densities of fresh water protozoans.

\section{Materials and Methods:-}

Simple experimental devices and convenient sampling equipments are required for protozoa assay to act as perfect bio indicators for aquatic pollution. For enumerating protozoa, a direct count method as suggested and described by Finley et al. (1979) was followed. The water samples were collected in a wide mouth glass jar, brought to laboratory within an hour and fresh live samples were analyzed on the same day. At the time of collection, disturbance and shock to protozoans was kept to minimal. Samples were transferred into beakers and allowed to adapt for 30 minutes. While studying, cultures were stored in areas of moderate light and temperature of $19-22^{\circ} \mathrm{C}$. These were kept covered with muslin to ensure air supply (Jens Boenigk et al, 2005).

Toxicity of four metals $\mathrm{Cu}^{2+}\left(\mathrm{CuSO}_{4} .5 \mathrm{H}_{2} \mathrm{O}\right), \mathrm{Cd}^{2+}\left(\mathrm{CdCl}_{2}\right), \mathrm{Zn}^{2+}\left(\mathrm{ZnSO}_{4}\right)$ and $\mathrm{Pb}^{2+}\left(\mathrm{Pb}\left(\mathrm{NO}_{3}\right)_{2}\right)$ were studied. For

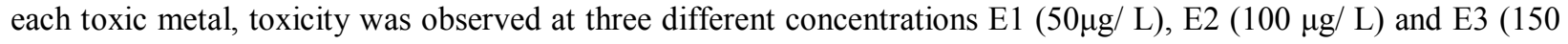
$\mu \mathrm{g} / \mathrm{L})$ as compared to controls in which no toxic elements were added. Using a micropipette, a drop of $5 \mu \mathrm{L}$ volume of pond water was delivered into a series of drops on a glass slide and at a magnification of 40X, the most of area covered by each drop remained within the field of view. The number of protozoans observed and identified in each $5 \mu \mathrm{L}$ were noted as $\mathrm{n}_{1}, \mathrm{n}_{2}, \mathrm{n}_{3}, \mathrm{n}_{4}, \ldots . . \mathrm{n}_{20}$ (Gasol J M, 1993). Variations due to different observers and to replicate series of counts were not significant. According to integrated density method the mean value of populations were taken $(n=20)$.

Mean $=\mathrm{n}_{1}+\mathrm{n}_{2}+\mathrm{n}_{3}+\mathrm{n}_{4}+\ldots . .+\mathrm{n}_{20} / \mathrm{n}$

The time interval between the addition of toxic substance and the first visible reaction was noted for all the observed individuals. Cell death was noted whenever possible. In addition toxic stress responses were investigated qualitatively for several protozoans of different taxonomic groups. Growth rates were calculated and tested by two way analysis of variance (ANOVA) to find the level of significance within permitted limits. 


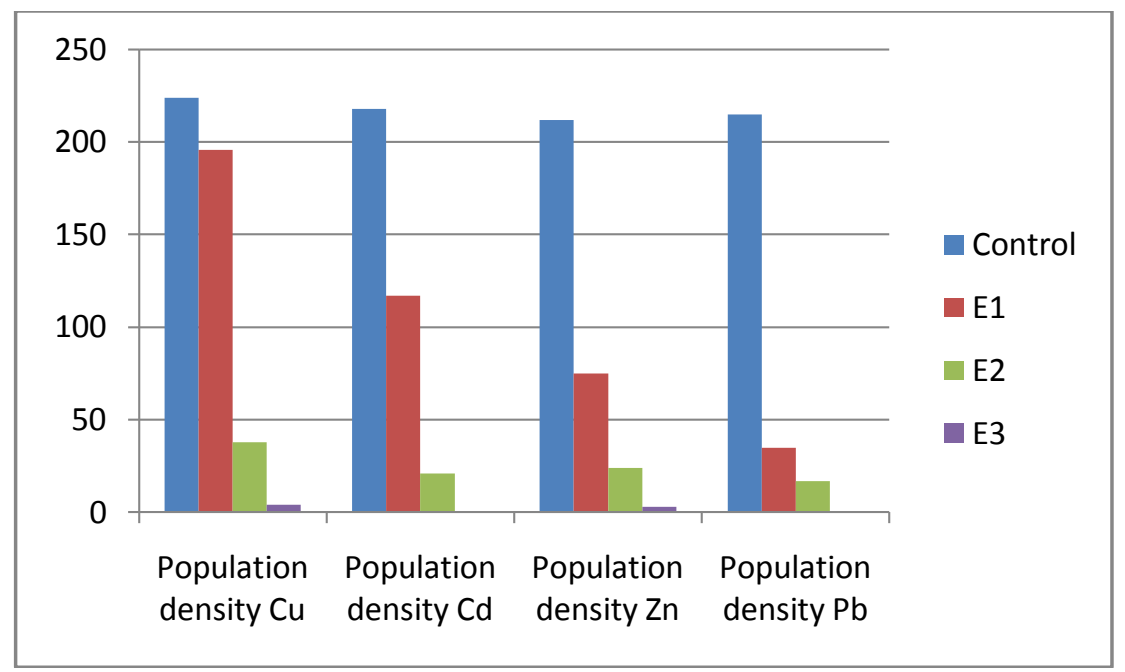

Fig 1:- Population densities of protozoans at different concentration of $\mathrm{Cu}, \mathrm{Cd}, \mathrm{Zn}$ and $\mathrm{Pb}$.

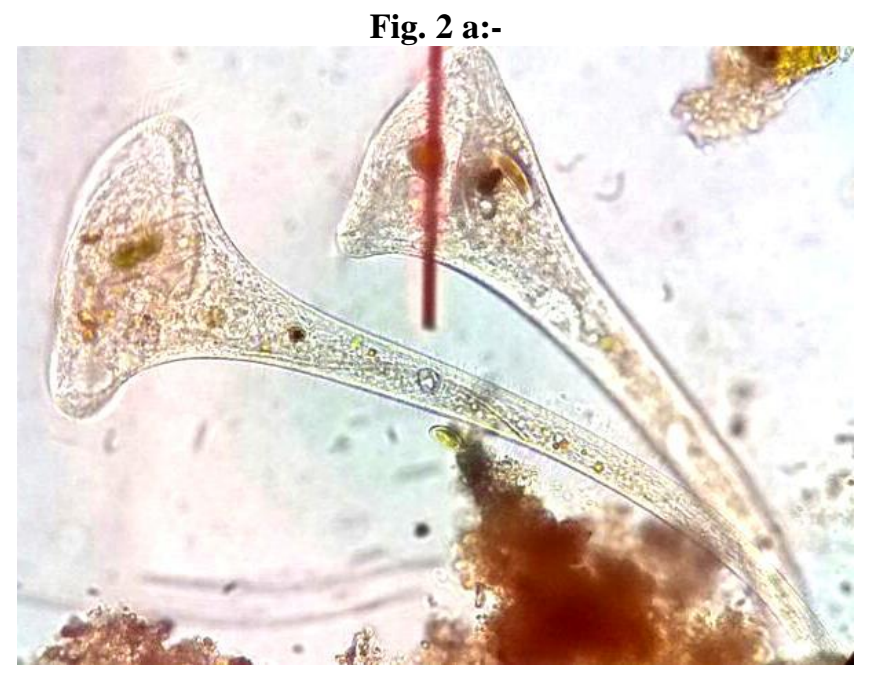

Fig. 2b:-

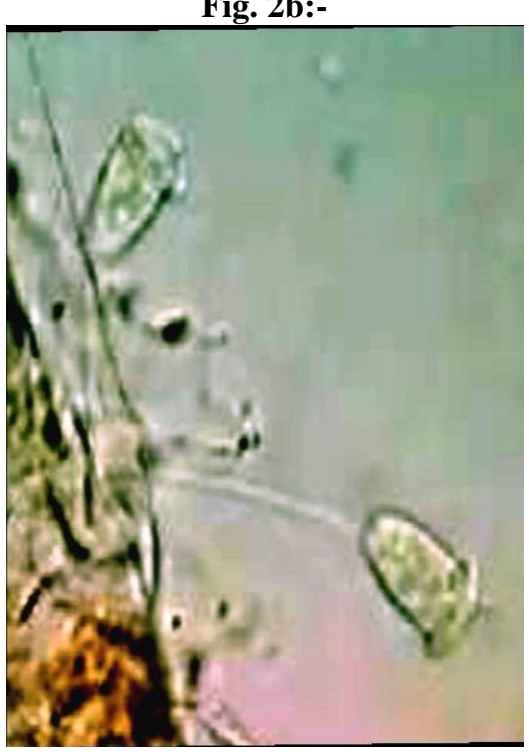


Fig. 2c:-

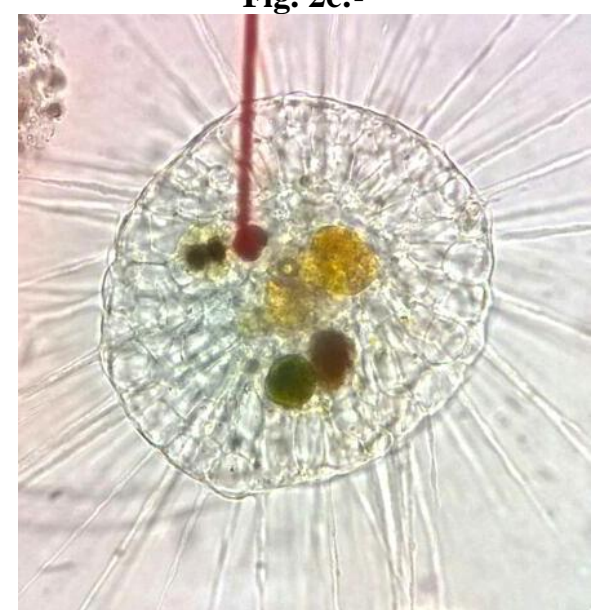

Fig. 2:- Non-lethal concentration without irritation (a) and stressful reaction (b) protozoans attached to surfaces and feeding upon bacterial mass on scum (c).

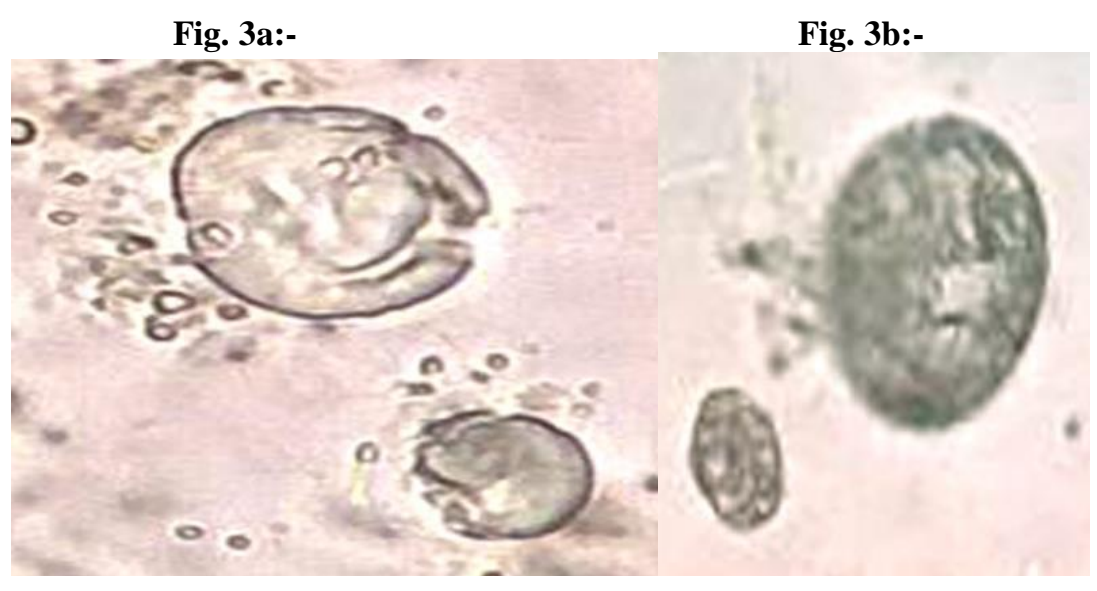

Fig.3c:-

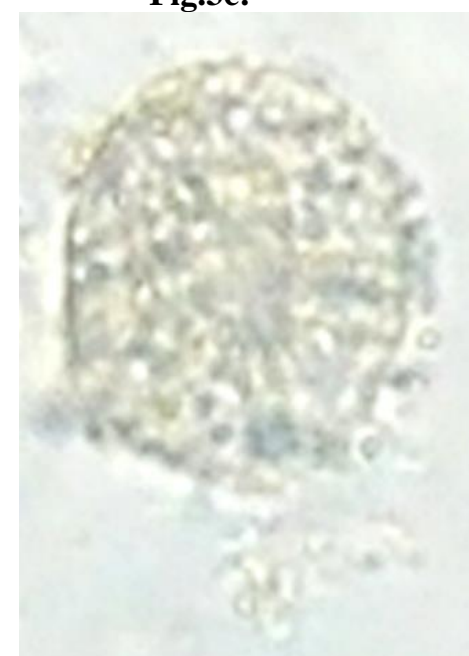

Fig. 3d:-

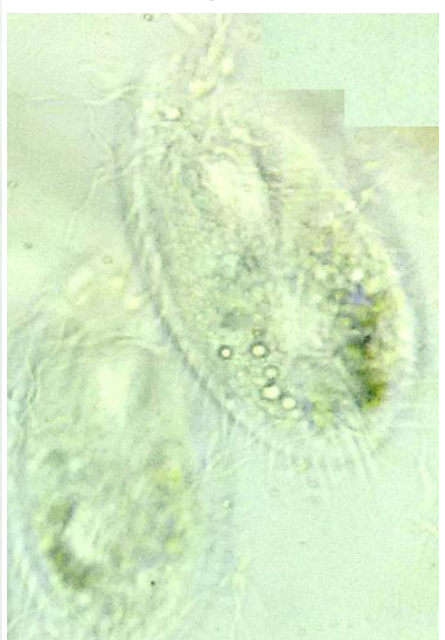

Fig. 3:- At highest concentration of toxic substances $150 \mu \mathrm{g} / \mathrm{L}$ (E3), (a) immediate cell bursting and blebbing ( b) stress egestion, (c) exocytosis and (d) erratic spinning and movement of cilia. 
Table1:-Population densities of Ciliates at three different concentrations of $\mathrm{Cu}, \mathrm{Cd}, \mathrm{Zn}$ and $\mathrm{Pb}$

\begin{tabular}{|l|c|c|c|c|}
\hline Concentration & \multicolumn{3}{|c|}{ Population Density (Number per drop of uniform size) } \\
\hline Control & $\mathrm{Cu}$ & $\mathrm{Cd}$ & $\mathrm{Zn}$ & $\mathrm{Pb}$ \\
\hline $\begin{array}{l}\text { E1 } \\
(50 \mu \mathrm{g} / \mathrm{L})\end{array}$ & $224 \pm 5$ & $218 \pm 6$ & $75 \pm 3$ & $215 \pm 4$ \\
\hline $\begin{array}{l}\mathrm{E} 2 \\
(100 \mu \mathrm{g} / \mathrm{L})\end{array}$ & $196 \pm 6$ & $117 \pm 4$ & $24 \pm 2$ & $35 \pm 3$ \\
\hline $\begin{array}{l}\text { E3 } \\
(150 \mu \mathrm{g} / \mathrm{L})\end{array}$ & $38 \pm 2$ & $21 \pm 3$ & $3 \pm 2$ & 0 \\
\hline
\end{tabular}

\section{Results and Discussion:-}

In the undisturbed samples of protozoa, after half an hour of transfer most flagellates were found attached to surfaces and feeding upon bacterial mass on scum taken in pond water samples. At a concentration of 50 $\mu \mathrm{g} / \mathrm{L}$ (E1) four elements $\mathrm{Cu}^{2+}, \mathrm{Cd}^{2+}, \mathrm{Zn}^{2+}$ and $\mathrm{Pb}^{2+}$ were found to be non-lethal in comparison to their respective controls and protozoans showed no irritation and no stressful reaction initially (Fig 1). However, at this non-lethal concentration, the first visible reaction observed were irregular beating of flagella and cilia and erratic spinning movements followed by initial blebbing by stress egestion and distorted cell shapes and eventual death of the cells as concentration of intoxicants was increased (Fig. 1). The results are in accordance with previous work which demonstrated increased frequencies of these irregular processes with increased dose of toxic metals. (Fernandez and Novillo, 1995; Madhoni et al, 1992; Manik and Manik, 2015 ; Vazquez et al, 2010). At highest concentration of toxic substances $150 \mu \mathrm{g} / \mathrm{L}(\mathrm{E} 3)$, the cells burst immediately within minutes with stress egestion and loss of flagellum (Fig. 3) For these four elements $\mathrm{Cu}^{2+}, \mathrm{Cd}^{2+}, \mathrm{Zn}^{2+}$ and $\mathrm{Pb}^{2+}$ at a concentration of $100 \mu \mathrm{g} / \mathrm{L}$ (E2), no living cells were observed after 24 hours in any of the treatments. The addition of these metals at E2 concentration significantly decreased growth rate of protozoans after 24 hours (Two way ANOVA, $\mathrm{p}<0.001$ )

At $50 \mu \mathrm{g} / \mathrm{L}(\mathrm{E} 1)$, maximum population density was found in $\mathrm{Cu}^{2+}$ followed by $\mathrm{Cd}^{2+}, \mathrm{Zn}^{2+}$ and $\mathrm{Pb}^{2+}$ indicating that $\mathrm{Cu}^{2+}$ is the least toxic element and $\mathrm{Pb}^{2+}$ being the most toxic element (Table 1). At $100 \mu \mathrm{g} / \mathrm{L}$ (E2), maximum population density was found in $\mathrm{Cu}^{2+}$ followed by $\mathrm{Cd}^{2+}, \mathrm{Zn}^{2+}$ and $\mathrm{Pb}^{2+}$ showing thereby $\mathrm{Cu}^{2+}$ as least toxic element followed by $\mathrm{Cd}^{2+}, \mathrm{Zn}^{2+}$ and $\mathrm{Pb}^{2+}$ in terms of increasing toxicity. At150 $\mu \mathrm{g} / \mathrm{L}$ (E3), maximum population density was found for $\mathrm{Cu}^{2+}$ followed by $\mathrm{Zn}^{2+}$ and zero population density was found in $\mathrm{Cd}^{2+}$ and $\mathrm{Pb}^{2+}$. This showed $\mathrm{Cu}^{2+}$ as least toxic followed by $\mathrm{Zn}^{2+}$ whereas $\mathrm{Cd}^{2+}$ and $\mathrm{Pb}^{2+}$ are highly toxic elements at $\mathrm{E} 3$.

The percentage decrease in population density at E1, E2 and E3 for $\mathrm{Cu}^{2+}$ recorded was 13,83 and 98 respectively (Table 1). For $\mathrm{Cd}^{2+}$ the percentage decrease at E1, E2 and E3 was 46, 90 and 100 and for $\mathrm{Zn}^{2+}$ the values are 65, 89 and 98 respectively. For $\mathrm{Pb}^{2+}$ the percentage decrease in population density was reported to be 84,92 and 100 percent at E1, E2 and E3 respectively.

Colonization rates expressed by the species number over time depicted a geometric regression of the average number of protozoa with increasing concentration of metals as compared to controls.

The organometallic complexes formed by $\mathrm{Pb}$ and $\mathrm{Cd}$ can show more toxicological properties than individual ions due to their high bio accumulation tendencies (Fernandez and Herrero, 1999)

\section{References:-}

1. Baldock, B. M. (1986) A method for enumerating Protozoa in a variety of freshwater habitats. Microb. Ecol. 12: 187-191.

2. Depledge M H, Weeks J M, Bierregaard, P (1998) Heavy Metals. In: Callow P. (ed) Handbook of Ecotoxicology. Blackwell Science, Oxford. Pp. 543-569.

3. Fernandez-Leborans G, Herrero Y O (1999). Toxicity and bioaccumulation of Cadmium in marine protozoa communities. Ecotox. Environ Safety. 43:292-300

4. Fernandez L G, Novillo A (1995). The effect of Cadmium on the successional stages of a freshwater protozoa community. Ecotox. Environ Safety.31: 29-36.

5. Finlay, B J, Laybourn J, Strachan I (1979) A technique for the enumeration of benthic ciliated protozoa. Oecologia(Berl) 39: 375-377. 
6. Gasol J M (1993). Benthic Flagellates and ciliates in fine freshwater sediments: Calibration of a live counting procedure and estimation of their abundances. Microb. Ecol. 25: 247-262.

7. Gupta P K and Shukla U (1996). Seasonal and spatial distribution of some benthic protozoa in an eutrophic freshwater lake of central Himalaya. Oecologia Montana. 5 : 100-105.

8. Gupta Ragini, Bhagat P, Joshi M, Inaotombi S and Gupta P K (2010). Heavy metal pollution status of lakeNainital, Uttrakhand. Indian J. Sci. Res. 1(1): 15-19.

9. Jens Boenigk, Anneliese W, Karin,P. (2005) Heavy metal toxicity and bioavailability of dissolved nutrients to a bacterivorous flagellate are linked to suspended particle physical properties. Aquatic Toxicology. 71: 249-259

10. Madoni P, Esteban G, Gorbi G (1992). Acute toxicity of Cadmium, Copper, mercury and Zinc to ciliates from activated- sludge plants. Bull. Environ. Contamin. Toxicol. 49: 900-905.

11. Manik V S and Manik S R (2015) assessment of heavy metals in ChhatriTalao, district Amravati, India during festival season. Journal of Environmental Research and Development. 9 (4) : 1172-1175.

12. Patricia M G, Efrain T S, Mahara V and Emilio R D C (2013) Biomarkers of exposure for assessing environmental pollution: from molecules to ecosystems. Rev. Int. Contam. Ambie. 29 (1): 117-140

13. Rand GM, Petrocelli, SR (eds). (1985) Fundamentals of aquatic Toxicology. Methods and Applications Hemisphere. New York. Pp. 374- 415.

14. Shakoori, A.R., Rehman A, Riaz-Ul-Haq (2004) Multiple metal resistance in the ciliate protozoan Vorticella microstomaisolatedeffluents and its potential in bioremediation of toxic wastes. Bull. Environ. Contam. Toxicol. 72: 1046- 1051.

15. Tsui, MTK, Wang WX. (2004) Uptake and elimination routes of inorganic mercury and methylmercury in Daphnia magna Environ. Sci. Technol. 38: 808- 816.

16. Valavanidis, A and Vlachogianni, T. (2010) Metal Pollution in ecosystems. Ecotoxicology studies and risk assessment in the marine environment. Science advances on environment, toxicology \& ecotoxicology issues. Pp. 1-14

17. Vazquez P Q, Sigee D C, White K N (2010) Bioavailability and toxicity of aluminium in a model planktonic food chain ( Chlamydomonas daphnia) at neutral pH.Limnologica. 40: 269- 277. 